\title{
Synthesis and Characterization of Iron Oxide Nanoparticles for Theranostic Applications
}

\author{
Marcela Cândido ${ }^{1}$, Nathanne Rost ${ }^{1}$, Andrea Campos ${ }^{2}$, Maiara Castilho ${ }^{3}$ Leandro Raniero $^{1}$ \\ ${ }^{1}$ Universidade do Vale do Paraíba/Instituto de Pesquisa e Desenvolvimento, Laboratório de Nanossensores, Avenida \\ Shishima Hifumi, 2911, Urbanova - 12244-000, São José dos Campos, Brazil \\ marcela.aparecida.candido@gmail.com; nathannerost@gmail.com; lraniero@univap.br \\ ${ }^{2}$ Aix Marseille Université, CNRS, Centrale Marseille, FSCM (FR1739), CP2M 13397 Marseille, França \\ andrea.campos@univ-amu.fr \\ ${ }^{3}$ Universidade do Vale do Paraíba/Instituto de Pesquisa e Desenvolvimento, Laboratório de Bionanotecnologia, Avenida \\ Shishima Hifumi, 2911, Urbanova - 12244-000, São José dos Campos, Brazil \\ mcastilho@univap.br
}

\section{Extended Abstract}

Iron oxide nanoparticles (IONPs) represent a class of magnetic and biocompatible nanomaterials, which has made important contributions for clinical diagnostics and therapies because of low-cost, viable preparation, and low cytotoxicity $[1,3]$. The biomedical applications include drug delivery, magnetic separation of labelling cells, development of therapeutic drugs, magnetic hyperthermia for cancer treatment, imaging agents, and others [1,3,5-6]. These nanoparticles exhibit typical superparamagnetic behaviour, with low Curie temperature and high magnetic susceptibility [2]. The chemical coprecipitation is a simple, easy and fast approach applied for synthesizing IONPs [3], in which a precursor aqueous solution containing ferric $\left(\mathrm{Fe}^{3+}\right)$ and ferrous $\left(\mathrm{Fe}^{2+}\right)$ ions are alkalinized under temperature and $\mathrm{pH}$ control. The reproducibility of this synthesis decreases due to parallel reaction pathways inherent in the method, that the formation of intermediate oxides occurs. Therefore, the reaction mechanisms of this chemical route are still the subject of research, but the main iron oxide phases formed are magnetite $\left(\mathrm{Fe}_{3} \mathrm{O}_{4}\right)$ and maghemite $\left(\gamma-\mathrm{Fe}_{2} \mathrm{O}_{3}\right)[4]$.

This work aims to synthesize IONPs by chemical coprecipitation and stabilize the surface with sodium citrate (IONPs@cit.). The characterization of nanoparticles were perform by Dynamic Light Scattering, Electron Microscopy, Fourier Transform Infrared Spectroscopy (FT-IR), X-Ray Diffraction (XRD) and Vibrating Sample Magnetometer (VSM). In order to evaluate the cytotoxicity of IONPs@cit, MTT assay was used to determine the mitochondrial activity in the MDA-MB-468 cell line. Different concentrations of IONPs@cit. were incubated in 1x10 cells for 6, 4, 2 hours and 1 hour.

The bare IONPs sedimented after the synthesis process, while the IONPs@cit were colloidal (Zeta Potential -54.0 mV at pH 8.0), however both had shown interaction with an external applied magnetic field (Neodymium magnet). The IONPs and IONPs@cit. were black in color, a factor that indicates the presence of $\mathrm{Fe}_{3} \mathrm{O}_{4}$, which was confirmed by FT-IR and XRD analyses. The hydrodynamic diameter values of IONPs and IONPs@cit. were both lower than 100 nm, this value will be compared to the physical diameter. VSM measurements confirmed the nanoparticles superparamagnetism. IONPs@cit had shown a low cytotoxic effect to MDA-MB-468 cells under the investigated conditions. In conclusion, superparamagnetic IONPs were successfully synthesized at the nanoscale and stabilized with sodium citrate, which show a great biocompatibility for biomedical applications.

\section{References}

[1] N. Eyvazzadeh. "Gold-coated magnetic nanoparticle as a nanotheranostic agent for magnetic resonance imaging and photothermal therapy of cancer". Lasers in medical science, v. 32, n. 7, p. 1469-1477, 2017.

[2] T. I. Shabatina. "Magnetic Nanoparticles for Biomedical Purposes: Modern Trends and Prospects". Magnetochemistry, v. 6, n. 3, p. 30, 2020.

[3] T. A. V. Pereira. "Nanopartículas de óxidos de ferro e nióbio com diferentes recobrimentos: síntese, caracterização e avaliação do potencial biológico". Tese de Doutorado. Universidade de São Paulo, 2018.

[4] A. P. Lagrow. "Unravelling the growth mechanism of the co-precipitation of iron oxide nanoparticles with the aid of synchrotron X-Ray diffraction in solution". Nanoscale, v. 11, n. 14, p. 6620-6628, 2019. 
[5] D. Ni. "Magnetic Targeting of Nanotheranostics Enhances Cerenkov Radiation-Induced Photodynamic Therapy". Journal of the American Chemical Society, v. 140, n. 44, p. 14971-14979, 2018.

[6] K. Hola. "Tailored functionalization of iron oxide nanoparticles for MRI, drug delivery, magnetic separation and immobilization of biosubstances". Biotechnology advances, v. 33, n. 6, p. 1162-1176, 2015. 